\author{
Dr. Alice Marwick \\ Postdoctoral Researcher \\ Microsoft Research \\ amarwick@microsoft.com \\ Dr. danah boyd \\ Senior Researcher \\ Microsoft Research \\ dmb@microsoft.com
}

\title{
The Drama! Teen Conflict, Gossip, and Bullying in Networked Publics
}

Last updated: 9/12/2011

\begin{abstract}
$\underline{\text { Abstract }}$
While teenage conflict is nothing new, today's gossip, jokes, and arguments often play out through social media like Formspring, Twitter, and Facebook. Although adults often refer to these practices with the language of "bullying," teens are more likely to refer to the resultant skirmishes and their digital traces as "drama." Drama is a performative set of actions distinct from bullying, gossip, and relational aggression, incorporating elements of them but also operating quite distinctly. While drama is not particularly new, networked dynamics reconfigure how drama plays out and what it means to teens in new ways. In this paper, we examine how American teens conceptualize drama, its key components, participant motivations for engaging in it, and its relationship to networked technologies. Drawing on six years of ethnographic fieldwork, we examine what drama means to teenagers and its relationship to visibility and privacy. We argue that the emic use of "drama" allows teens to distance themselves from practices which adults may conceptualize as bullying. As such, they can retain agency - and save face - rather than positioning themselves in a victim narrative. Drama is a gendered process that perpetrates conventional gender norms. It also reflects discourses of celebrity, particularly the mundane interpersonal conflict found on soap operas and reality television. For teens, sites like Facebook allow for similar performances in front of engaged audiences. Understanding how "drama" operates is necessary to recognize teens' own defenses against the realities of aggression, gossip, and bullying in networked publics.
\end{abstract}

\section{$\underline{\text { Introduction }}$}

His girlfriend, Brittany, cheated on him and she went and partied really hard and got drunk and cheated. And then it was all over Formspring. A lot of people are like, "You can do better than that slut" and stuff. And people 
would write on hers, "You're such a cheating whore" and blah, blah, blah. And so, that was like drama and stuff. And like, I know Brittany Martinez. If I saw her, I'd be like, “Hey, what's up?" But I don't know her personally. And so, I wouldn't go talk to her about it. But I read that and I could know about it. So it was kind of just like drama I could [see] and stuff.

\section{Victoria, 15, Nashville}

When American teens talk about their day-to-day lives, drama invariably comes up. Drama is the language that teens - most notably girls - use to describe a host of activities and practices ranging from gossip, flirting, arguing, and joking to more serious issues of jealousy, ostracization, and name-calling. In contemporary teenage life, relationships and social ties play out in networked publics like Facebook, Formspring, Tumblr, and Twitter. On these sites, drama takes place in front of an audience. Teens use the affordances of social media to gather attention, involve themselves in others' lives, and manipulate "public" perceptions. As the term "drama" suggests, the visibility of interpersonal interactions in networked publics connotes performance and publicity. In the above quote, Victoria is intimately familiar with the details of Brittany's transgressions without having a personal relationship with her that would indicate such an understanding. Brittany supposedly cheated on her boyfriend in a relatively public venue - a party - and the consequences of her actions, perceived or actual, also played out publicly. Victoria watches from afar while maintaining only a casual acquaintanceship with the players. While this could happen in the school hallways or at the mall, it is available to a larger and more engaged audience on sites like Formspring and Facebook.

Drama ranges widely and can include: posting what teens often refer to as "inappropriate" videos and photos and the resulting fallout; conflicts that escalate into public standoffs; cries for attention; relationship breakups, makeups, and jealousies; and a vast array of aggressive or passive-aggressive interactions between friends, enemies, or "frenemies". In this paper, we examine the key components of drama, how teens practice drama, and the cultural work it does in their lives. We argue that the term "drama" allows teens to distinguish their actions from adult-defined practices like bullying or relational aggression. Drama blurs distinctions between the serious and frivolous as well as what is just joking and what truly hurts. Dismissing conflict as drama lets teens frame the social dynamics and emotional impact as inconsequential, allowing them to "save face" rather than taking on the mantle of bully or victim. Moreover, the gendered nature of drama, often

\footnotetext{
${ }^{1}$ A "frenemy" is someone who, at least at the surface, appears to be a friend but with whom there is great distrust and uncertainty about the relationship. Urban Dictionary defines a frenemy as both "an enemy who is disguised as a friend" and "a relationship that is both mutually beneficial or dependent while being competitive [and] fraught with risk and mistrust." http://www.urbandictionary.com/define.php?term=frenemy
} 
dismissed as a "girl thing," reinforces a heterosexist script of high school life in which feminized emotional work is devalued. Finally, drama is intrinsically performative, in that it takes place in front of a networked audience, which engenders new dynamics and complicates distinctions between what is public and private. Drawing from six years of ethnographic fieldwork, we examine how American teens conceptualize drama, its key components, participant motivations for engaging in it, and its relationship to networked technologies.

\section{Methods}

This paper draws on ethnographic data collected from 2006-2011 across the United States, including 16590 -minute semi-structured interviews and two discussions of drama with three teen girls from different schools conducted in the Boston area in 2011. The participants ranged in age from 13 to 19 . We strategically worked to elicit perspectives from diverse teens, playing close attention to gender, race, ethnicity, religion, age, socioeconomic background, political background, and school engagement level. All names and identifying information have been changed to protect the privacy of our informants. Whenever possible, we obtained concrete examples of drama from our participants, including Facebook and Formspring data.

\section{What is Drama?}

Drama: "Something women and especialy [sic] teenage girls thrive on. consisting of any number of situations that have an easy solution, wich [sic] would bring a fairly good outcome, but these girls choose another, shitty, bad way to deal with it, again consisting of backstabbing, blackmailing/gossiping/betraying their friends, or the all-too-common 'I want to break up with him but i still love him!' it drives men and what i like to call 'normal' girls nuts." (Urban Dictionary, 2005)

Our interest in the term "drama" started with a series of interviews we conducted in the autumn of 2010 in the Southeastern United States. The focus of these interviews was privacy. We wanted to learn how teens balance their personal boundaries with a social milieu where putting information online is normal and expected (boyd \& Marwick, 2011). When we asked teens about privacy, they frequently answered using different language. This was unsurprising; we had learned that many terms that appear in scholarly and popular literature - like "cyberbullying," "relational aggression," or "informational privacy" - are not part of the day-to-day lives or vocabulary of American teenagers. While looking for a way to understand teens' privacy strategies, we became interested in "drama." Talking with teens about drama helped us understand their attitudes about privacy, but it also piqued our curiosity more generally. 
Among the teens we observed and interviewed, drama appears to be ever-present. Drama is an emic term used by both teenagers and adults to describe interpersonal conflict that takes place in front of an audience. Drama connotes a combination of conflict and attention that often involves social media sites like Twitter, Facebook, MySpace, and Formspring. On these sites, drama is played out publicly, using the affordances of social media to reproduce relational forms of aggression, gather publicity, and manipulate perceptions. Although drama does not need to take place on social media sites, it often does.

danah: How does it [drama] come out on Facebook?

Alicia, 17, North Carolina: Well, there's a girl from West Beverly that got in an argument with a girl from South Beverly and they were at a party. So then when I looked on Facebook the next day there were all of these comments on [there] like "I love you, I don't think you're a - whatever the girl called her." So it's all really immature and they'll put statuses up like "oh my gosh I'm so over this." So that's how drama gets on Facebook.

Alicia's story shows how the Facebook Wall can be used to demonstrate public support for one side of a conflict. A status message like "oh my gosh I'm so over this" is intended to elicit support and feedback. Not only can friends respond with supportive comments, but they can also click the "Like" button, which appears on each message to show their affiliation in an interpersonal interaction. This is just one way in which Facebook is employed in teen dramas.

As we talked with teens, we quickly became interested in their use of the term and how the concept works in their lives. "Drama" connotes something immature, petty, and ridiculous. The word connotes playacting on a stage, flippancy and triviality. Teens accordingly denigrated people who stirred up drama as attention-getters trying to entangle themselves in conflicts that did not involve them. Those who admitted to purposefully starting drama either talked about doing so for entertainment or justified starting a fight using issues like jealousy. Still, these teens talked about drama as if it was not a big deal, but simply a natural or normal part of teen life.

For all the work teens did to minimize the psychological and social importance of drama in their lives, we noticed that the dramas they identified did actually affect them and were, in some circumstances, quite hurtful. Yet, by using the language of "drama," teens were able to lessen the importance of conflict in their lives, blur the lines between serious and non-serious actions, acknowledge the intrinsic performativity of teen life on networked publics, and - most importantly - "save face." Erving Goffman (1967) highlights that people engage in "face-work" to give the impression that whatever they're doing or feeling is consistent with the image that they seek to present about themselves. Thus, by using the 
term "drama" in lieu of "bullying," teens side-step adult-defined subjectivities of "bully" and "victim" in order to position themselves and their practices as normal.

\section{Defining Drama}

Defining drama is not easy; its conceptual slipperiness is part of its appeal. To the teens we talked with, drama was like Justice Potter Stewart's definition of pornography: you know it when you see it. Yet, colloquial definitions of drama - such as the most popular one quoted above from Urban Dictionary, a site that uses user-generated content and voting mechanisms to define colloquial terms - focus on highly fraught social interactions between known interlocutors who are, predominantly, women and girls. Another, simpler definition offered by Urban Dictionary is: "making a big deal over something unnecessarily."

What constitutes drama differs across communities. For instance, physical aggression may be a key component of drama in some areas, while fighting is outside the boundaries of drama in others. It is radically different for a teenage girl to engage in physical aggression in predominantly White middle-class neighborhoods, which encourage young women to suppress anger, than it is in poor Black and Latino communities, where girls are expected to stand up for themselves verbally and physically (Ness, 2010). Alice asked Rashna, a 16 year old girl from Chicago, to define drama:

The definition varies from friend group, like where the school is. I think each community has its own sense of drama. Like her [Naila, another girl in the room] sense of what is drama, like the fact that fights go on, that doesn't happen at my school. That doesn't happen at Carmen's school. And I think that drama will vary based on where it is, like the suburb or city, like geographically, maybe how much money the school has, and how much people they have in school. So I don't know if you'll ever be able to pin [it] down.

While Rashna, Naila, and Carmen agreed that there were differences in drama between their schools, we also found definitional differences within schools, suggesting that teens view drama differently depending on their social status and friend group norms.

In trying to unpack what drama means to teens, we identified five key components:

1) Drama is social and interpersonal

2) Drama involves relational conflict

3) Drama is reciprocal

4) Drama is gendered

5) Drama is often performed for, in, and magnified by networked publics 
Drama is social and interpersonal, involving other people and relationships. Unsurprisingly, drama intrinsically involves conflict. Sometimes this takes the form of strong moral evaluation of other people's behavior. In the opening example of the paper, Brittany's behavior was judged to be "slutty" or "cheating" by her classmates. Other times, a minor disagreement between friends blows up and mutual friends are forced to take sides. It is also reciprocal. As Carmen, a 18-year-old from Boston said, "you can't have drama by yourself." She explained that keeping problems or conflicts to herself was a way to avoid drama; posting an opinion on Facebook or in a text message could spark conflict, which she tried hard to avoid. Other teens talked about the involvement of other people "with no lives" who jumped into arguments "where they didn't belong." The participation of bystanders and onlookers distinguishes drama from bullying, where power is often unidirectional. Fighting is one thing, but fighting back creates drama.

Drama is also gendered. It is conceptualized as a "girl thing" and dismissed in kind. Participating in drama is seen as deeply un-masculine, but at the same time, boys are often the cause of drama as potential or actual romantic partners. They are also, at times, the instigators of drama because, as one boy told danah, "It's fun to watch girls fight." Boys do, however, engage in their own forms of social conflict and gossip - including practices they identify as "punking" and "pranking." Their practices often have an element of machismo to them. Both the practices associated with boys and the dramas associated with girls amplify gender differences while reinforcing the power dynamics of high school life that emphasize girls' ability to attract boys as a primary status marker. Drama thus reinforces and re-inscribes conventional gender roles and heterosexuality.

Finally, while drama can, in theory, emerge without involving social media, it became clear in our fieldwork that social media - and the networked publics that emerge out of social media - play a critical role in how drama is constructed in contemporary teen life. Drama plays out on, and is enmeshed with, teens' engagement with social media. As such, it is impossible to untangle drama from the networked publics in which it operates. Boyd defines a networked public as "(1) the space constructed through networked technologies and (2) the imagined community that emerges as a result of the intersection of people, technology, and practice" (2008). Popular social media like Facebook and Tumblr enable networked publics to form and serve as networked publics themselves. They are both a site of engagement and a tool for enabling communication among an existing social network.

Many of these features, while key components of drama, are not unique to drama. As a result, drama often resembles other social processes - including bullying, relational aggression, and gossip - but key social and cultural factors set it apart.

What Drama is Not 
While drama can resemble bullying, relational aggression, or gossip, it is distinct from these three practices. Drama extends many of the tropes and themes of gossip into social contexts that are rich in social media and different understandings of public-ness. Likewise, because relational aggression - the Mean Girls model of feminine conflict - harnesses interpersonal ties rather than physical altercations, there are significant parallels between drama and relational aggression. Yet, jokes, pranks, misunderstandings, and cries for attention can also fall under the umbrella of "drama" even though they are not forms of relational aggression. Finally, while bullying can and does go on within networked publics, the reciprocal element of drama distinguishes it from traditional constructs of bullying. Because the technical affordances of social media allow for both public-ness and participation, contemporary drama incorporates elements of gossip, bullying, and relational aggression while remaining distinct from each.

\section{Bullying}

The canonical definition of bullying, written by Dan Olweus, includes three components:

1. Bullying is aggressive behavior that involves unwanted, negative actions.

2. Bullying involves a pattern of behavior repeated over time.

3. Bullying involves an imbalance of power or strength (Olweus, 2011).

Differential social or physical power and directed aggression are both key to how bullying is conceptualized in scholarly literature. While drama may involve differences in social power, it also often occurs between "friends" who are on even social planes. More importantly, while reciprocity is not central to how bullying plays out, it is a core component of drama.

While the current move in public discourse is to lump all relational aggression into the colloquial category of "bullying," teens often recognize the differences that Olweus set out to highlight. For example, Carmen, a 18-year-old in Boston, distinguishes between drama and bullying by defining drama as having an active, agented role:

Drama is more there's two sides fighting back. I guess the second you fight back, it's- you're not allowed to call it bullying because you're defending yourself, I guess. But like, for example, my gay friend, these people spit tobacco in his locker. And I would consider that bullying, not drama, because like these are people who don't have a beef with him. Like they don't know him. They just know he's gay, and [think] "I'm going to spit tobacco in his locker." 
For Carmen, drama is bidirectional, while bullying is directed. Unlike bullying, there are no victims in teens' model of drama. To avoid drama, teens are expected to simply refuse to participate, while it's assumed that they cannot avoid being bullied.

\section{Relational Aggression}

At first glance, drama looks like a form of relational or indirect aggression, concepts which came into public consciousness through the book Queen Bees and Wannabees and the film Mean Girls (Remillard \& Lamb, 2005; Wiseman, 2003). Relational aggression is often conceptualized as a feminine, middle-class way of bullying others. According to scholars, girls engage in indirect and relational aggression because it is socially and contextually unacceptable for them to engage in physical aggression (Jack, 1999; Ness, 2010; Simmons, 2003) Because women and girls are judged harshly for anger and aggression, their use of teasing, gossip, and ostracization allows them to express these feelings in a socially condoned way (Jack, 1999; Ness, 2010). Like relational aggression, drama is a feminine-gendered practice. It also intrinsically involves the interpersonal, which is what distinguishes relational aggression from physical aggression. Participants in drama can manipulate social ties, popularity, and status, just as those engaging in relational aggression do. In fact, some forms of drama constitute relational aggression, with the hurt feelings and psychological impact to prove it.

But drama goes beyond both relational aggression and bullying. Drama can encompass joking around, practical jokes, sarcastic asides, and performative play-fights. It can go on between two members of the same social circle with equal power dynamics. It includes tactics like posting provocative photos or moribund comments to get attention. And it can involve conflicts between teens who do not even know each other. Naila, an 18 year old Muslim girl from Boston, told a story to illustrate a point:

There's this one girl, she posted a picture on Facebook. It's like a regular picture, she was at the movies. And she has two different groups of friends. She has her really like hoity-toity white friends. And then she has her school friends. I'm not saying they're ghetto or anything, it's just like city kids. And so she had like new Jordans on. So her really like hoity-toity friend was like, "Oh, it's a cute picture, but what the hell is on your feet?" And this one girl from school who's a really good friend of hers was like, "Clearly, they're Jordans. And they're like that expensive, and they're like this and that." And this other girl, her white friend was like, "Excuse me, who invited you into this conversation? I was clearly commenting on X-Y-Z, my best friend's photo, and where I come from, Jordans are ghetto." And they just kept going for like- it got to like 53 comments. 
In this case, an inoffensive picture posted to Facebook sparked drama between two groups of teens with different mores and norms. To Naila's school friends, expensive sneakers were recognized as a major status symbol. But to the "white girls" from the other side of town, they were tacky and racially marked. The use of the word "ghetto" incited both class and racial tension that came to a head on the comment section of a Facebook photograph. Drama can be sparked by even seemingly-innocuous statements between discrete social groups, and does not necessarily involve close friends or even acquaintances. It is not always motivated by aggression.

\section{Gossip}

Like gossip, drama intrinsically involves social events or elements. But the two are distinct in other ways. The anthropologist Gary Fine writes that gossip is a "form of discourse between persons discussing the behavior, character, situation or attributes of absent others" (1997, p. 422). In other words, gossip requires its subjects to be elsewhere. This is quite different from drama, where the subjects are usually involved and potentially the instigators. Drama does not take place in tiny, intimate groups, but in large social sites with extensive potential audiences which constitute networked publics. Because these environments are public-by-default, private-by-effort, it becomes very difficult to talk "behind somebody's back." Drama can be triggered by a tagged photo that shows up on a teen's profile, whether or not she wants to be involved.

Folami, 18, Tennessee: Facebook is fun when there's Facebook drama on somebody's Facebook status. That's like, I don't know, it makes it even more fun when people start acting ridiculous on Facebook and everyone can see it.

danah: So what's an example of Facebook drama?

Folami: I think like when people have statuses there about someone or their boyfriends.

Mei Xing, 17, Tennessee: About relationships.

Folami: In relationships. And you can't really - even though they don't put names on it you know who they're talking about and everyone sees it. Mei Xing: I love seeing the little hearts on Facebook because it's always like someone just got in a relationship or someone just broke up.

Mei Xing and Folami enjoy seeing classmates break up or make up. By any standards, such events constitute juicy gossip. But once people post thinly veiled status messages about these relationships, they become drama. These status messages, for all intents and purposes, are public commentary. While Mei Xing telling Folami that two friends broke up 
may be gossip, one of those friends posting a negative status message about his exboyfriend constitutes drama.

When asked to distinguish between "drama" and "gossip," the lines seemed indistinct, although teens saw them as very separate.

Carmen, 18, Boston: I like to think of gossip as more like passiveaggressive. Drama is like it's happening now, and it's like, "Oh, my god, it's explosions!" And gossip, I think more like, "Oh, my gosh! Did you hear about this?" But it's like a, "Did you hear about this?" It's not like, "I'm going to go fight that person now, because they did this, this, and this." And you gossip about drama.

Rashna, 16, Chicago: I think gossip is usually based off a story that is very, very far from the actual event. Whereas, drama is more based off-it's closer to what's actually happening. Whereas, gossip might just be a fabrication or a complete lie about what's going on. And it's not really based off of anything that actually happened. Naila, 18, Boston: Or in my case, gossip is more removed from yourself. Like someone will be like, "Oh, my gosh! Do you have any gossip?" And it'll be like, "So-and-So broke up with So-and-So." But it's not something that's happening drama towards you, I guess. It's not like, well, gossip is more like, "Oh, you know that perfect couple that isn't in my group that's kind of over there, they broke up."

To these girls, drama is more present, more significant, and more "real" than gossip, which seems removed, or even completely fabricated. Carmen's description of drama as "explosions" shows the importance and immediacy of drama to their lives, even as they dismiss it as silly or unnecessary.

Fine argues that when people are gossiping, they use language and conversational strategies to ensure that the participants "inhabit the same moral universe" (1986). In other words, through gossip, teens try to define the boundaries of acceptability, allowing them to construct and refine their own morality and sense of social norms. Statements like "Did you hear about this?" allow teens to both make certain they are mutually aware of a particular event and signal their own attitude towards it. Making judgments is also a central component of drama.

danah: And tell me about drama, what kind of drama?

Matthew, 16, North Carolina: Oh my gosh, so there will be like, for example, I'll just quote something like they'd be like "So today I was riding home in my car and this girl pulls me up to me and she flips me the bird and I thought it was terrible." And then she'll write about her and her status or 
something like that, or in her little comment thing. And she'll be like, "She's such a bitch and I cannot take her anymore and I absolutely just cannot stand her." And you're just like really? Do I need to hear this?

Matthew identifies two types of evaluative behavior in his example. The original status message is written by a girl offended by an obscene gesture, and Matthew expresses frustration with the original poster's publication of what, to him, is a relatively unimportant incident.

While drama often includes gossip - or erupts in response to gossip - they are not equivalent. More than anything, drama can be distinguished from gossip by the involvement of the relevant people. Being gossiped about is one thing; responding to and engaging in gossip about oneself is drama.

\section{Drama as Practice}

The ways that drama is practiced by teenagers take several different forms, all related to publicity. The integration of networked publics into teenage social life enhances the performative aspect of interpersonal conflict. Teens are aware that they are being watched by an audience of their peers, and they use the technical affordances of social media accordingly. Moreover, being the bearer of drama can boost status and popularity and serve as a mechanism to obtain social capital. Drama becomes a form of entertainment, much like reality television or tabloid magazines. It is watched by bored teens and often stirred up to give the perpetrator something to do. The public or semi-public nature of sites like Facebook or Twitter affects how conflict plays out in teenage social groups.

\section{Performativity}

Drama is a performative set of actions undertaken to involve an audience. Just as Erving Goffman conceptualized a "front stage" and a "back stage" for interpersonal interaction and identity presentation, drama typically takes place on a stage that is organized around high school (1959). In most American high schools, social media have replaced the street or coffee shop as the "place" where much of the discussion, interaction, and "hanging out" between teens goes on. In virtually every town where we conducted fieldwork, we found that it was normal for teens to "friend" everyone in their class or school. This results in large potential audiences for Facebook messages that can involve people far beyond the original participants. Thus, when teens turn to social media to socialize, their conflicts often take place in front of a highly distributed networked audience that consists of a large group of classmates and acquaintances, not simply close friends. This magnifies the visibility of dramas that take place, especially when the networked audience comes together to respond to particular posts. 
Amira, 15, Tennessee: There was this girl and she put up a picture and I guess it was like she was making a Botox face like where your eyes are like this [half-closed] and you like try to make your lips look bigger. And so this girl commented to her and she's like, "Botox much?" And then the other girl comments on it and then they just start cussing each other out. And then the next thing you know everyone jumps in and they're like cussing each other and it's all this is really funny because like in person they'll just walk past each other and they won't do anything.

Drama can start on networked publics or it can begin in face-to-face settings before shifting online, but networked publics are almost always involved. In Alicia's earlier anecdote, drama began at a party between girls from two different high schools and then moved to Facebook, where it was enacted for a larger audience than the original partygoers. In Amira's story, drama arose from the comments of a Facebook photo. While the drama that Amira references didn't spill out into the hallway, other dramas do. In some incidents, what takes place on Facebook is thought of as separate and distinct, but, more often, networked publics simply extend unmediated social spaces like school and parties.

Rashna, 16, Chicago: There's no removal from what happens at school. Cause it can always continue on Facebook, and you have access to that at your home. Which previously was considered somewhere where you don't have to deal with everything that's going on in school.

Rumors, gossip and drama circulate on Facebook and Twitter while moving back and forth between the school corridor and instant messenger, texts, and written notes. Drama exists beyond a single media.

Networked publics also increase the mechanisms of participation involved in drama. In analyzing the mechanisms of gossip, Gary Fine explains that "gossip is embedded in conversation, and so constitutes a performance with an audience: the audience's presence and reactions shape and direct the gossip" (1986, p. 408). This holds true for drama as well, but networked publics offer additional forms of participation, both for those directly involved in the drama and for those who enjoy observing it. Not only do networked audiences shape, spread, and direct drama, they fan the flames that allow it to escalate. Without audience engagement, dramas can burn out faster. For example, the party fight that Alicia describes might simply have turned into gossip if it weren't for Facebook. Once the key actors began to engage on Facebook, the drama escalated as more people jumped in to share their opinion or offer support.

Mei Xing and Folami's discussion of "the little hearts on Facebook" shows that interaction with an audience is not always easily detectable unless one is looking. In this case, the girls enjoy reading and talking about the drama that their friends and classmates 
get into. Mei Xing and Folami may chat about it on IM or in person, or they may involve themselves further in the conflict by "liking" a status update or reblogging a Tumblr post. They are active participants, but their practices of listening and taking sides aren't nearly as noticeable as those who add comments. Drama allows for a spectrum of participation from the audience, but not all participation - or all drama itself - is easily recognizable

Drama allows for a spectrum of participation from the audience, but not all participation - or all drama itself - is easily recognizable. When danah was looking at Serena's Facebook, she noticed a status update that said, "I'm sick and tired of all of this." It was "Liked" by more than 30 people. Confused, danah asked Serena to explain what was going on. The 17-year-old from North Carolina launched into a long discussion about the different dramas taking place in her school. Apparently, Cathy had posted "She's such a bitch," a veiled message about another girl, Kristy, and it was liked by many of her friends. Kristy - the author of the "I'm sick and tired of all of this" message - felt the need to respond in kind. While such performances are effectively rendered invisible for outsiders, such as us, they are highly visible to those in the know. This is just one example of the kinds of privacy strategies that teens take to simultaneously perform for broad audiences while simultaneously narrowing the audience (boyd \& Marwick, 2011).

The instigators of drama may wish for a certain reaction, but they have no guarantee of getting it, nor are they always able to see it if they do. Yet, the involvement of supposed onlookers fuels the fire. It is the public nature of social media that creates - or scales drama. The moment that gossip becomes fodder for the networked public is the point at which it becomes potential drama. Since drama moves from software to site to physical space to media and back, there is a scale of visibility. Some drama is immensely public, and is visible to massive audiences. Other drama is behind-the-scenes or confined to a small group, but still involves an audience. It is not the size of the audience that determines drama, but its existence, combined with mechanisms to marshal allegiance. Networked publics provide both a platform for visibility and tools that allow for support. As such, drama almost always spills out into social media.

\section{Attention}

Some teens enjoy the attention that instigating or performing drama brings with it, whether that be negative or positive. Madison recognizes that peers of hers are regularly seeking attention by performing for everyone around them.

Alice: Do you think some people do stuff to get attention on Facebook? Madison, 16, North Carolina: Definitely, like people that'll hang out that day then they'll be like "Oh hey, it was great hanging out with you today," it's like "That's not necessary, not everyone needs to know that you were 
hanging out with that person." Or after you have a crazy night writing on someone's wall "Crazy night last night." That's just trying to get attention.

Both the performative and attention-seeking aspects of drama are obvious to Madison. In another interview, Heather offered the story of her friends Erin and Anya, who were fighting over a boy. Erin argued with Anya on her wall so that "everyone [would] back her up." Heather sighed, "I guess things are just more dramatic if they're on the wall, and Anya wants everyone to see how unfairly she's being treated." The affordances of social media sites like Facebook or Formspring mean that content can be broadcast to a very large audience of interested bystanders. Teens often formulate status messages and pictures specifically to gain attention from their friends and classmates. Conflicts are played out publicly in order to marshal support for one side or another. The fact that arguments have audiences allows other people to get involved in situations they were not originally a part of, furthering and continuing drama (Veinot, Campbell, Kruger, Grodzinski, \& Franzen, 2011).

The question for attention is often discussed in gendered terms, with boys identifying attention-seeking as the primary motivation for girls' engagement in drama. Matthew, a 16-year-old from North Carolina, astutely explains:

danah: Why would they answer those [Formspring questions]? Matthew: The people who do it it's the attention [they] crave, for sure. It's the only way I can say it. The girls who do that are the girls who watch "Gilmore Girls" or "Gossip Girl" better yet. So it's like those girls who love a little drama in their life or something. I don't know, it's a good way for things to get around too. So if there's a rumor they can confirm or deny it on there. And depending on that, how they answer it, you have yourselfthere's this big new piece of news about so-and-so that you can spread around which, I think, is kind of cool.

While boys also seek attention - especially from girls -attention-seeking activities are gender-segregated in terms of acceptability. Girls can be quite public in their quest for attention from peers, but boys' interest in attention must be marked more subtly. For example, one girl posted a Facebook message saying "You've got blank percent of my heart: Like my status to see how much." If her friends "Liked" the status, she would respond on their Wall by saying how much she cared about them. This type of game allows girls to directly ask their audience for an action. When the audience gives attention explicitly and visibly, the performer gets something in return that makes them feel validated. But these games are rarely engaged in by boys, and not all girls find them endearing. Taylor, for instance, is an artist who posts pictures of her artwork and photography on Facebook: 
danah: So you pointed out that you like the attention on your comments. So what's the difference between those kinds of attention?

Taylor, 15, Boston: I don't draw people into my personal business, I draw them into my artistic business and I like their feedback when they say that things are good or bad but I don't want people, if I broke up with my boyfriend, I don't want people, they would see that I broke up with him and so of course they would start commenting on -- when you break up with somebody on Facebook it posts it and you can't really stop it from posting, because when you change your relationship status, that's what happens, so people would comment on that, but I'm not going to write something myself and say I'm heartbroken and I can't believe he did that.

Taylor likes getting feedback on her work, but she doesn't want people in her relationship or conflicts with friends. She wants feedback on her artistic accomplishments, but she looks down on female classmates who post needy messages asking for support. Taylor sees her own calls for attention as positive and affirming rather than overly emotional or negative.

\section{Status}

For many adults, teens' obsession with status and popularity seem immature, but in the context of teen life, it makes sense. Lacking any significant economic or political power, teens use status as an organizing structure. As Milner explains, teens have "one crucial kind of power: the power to create an informal social world in which they evaluate one another" (2004, p. 4). The dramas that teens produce and engage in help serve their investment in status.

Information can serve as fodder for social capital, particularly for girls. Having a juicy piece of gossip gives girls status: if they can get someone to confirm or deny a rumor on Facebook or Formspring, they can tell everyone about it. Other teens seek out secrets, putting together pieces of information from disparate sources. This process, often called "Facebook stalking," allows the gossip purveyor to create narratives that are more than the sum of their parts (Marwick, 2011). Whether accurate or not, determining that two classmates are dating from hints on their Facebook or Twitter pages can boost the investigator's popularity, and give them valuable ammunition to cause drama. Gary Fine frames gossip as having transactional value (1997). Having an important piece of information increases the importance of the person who tells it.

Being involved in drama is, in itself, a mark of popularity, as Naila explains:

danah: So what's the value of drama?

Naila, 18, Boston: Popularity. Something to do. The more drama you're involved in, the more likely you're popular, because you're dealing with 
high-end or high-stakes like events. Because like, “Oh, I don't want to deal with people coming into my party," but clearly, you're throwing a party in the first place. You're clearly selecting a group of people. You're clearlyyou know what I mean? You're actively participating in drama. You're like putting yourself out there available for a drama. You're allowing a space for that to happen. Whether it happens at your place or not, or like around your space, you're inviting it in.

The more popularity a high school student has, the more likely they are to be gossiped about or known throughout the school. Drama can also be used to manipulate impressions about another person - often someone the instigator doesn't like - and control the flow of information strategically. Damaging other people's reputations can be a way for girls to pursue social goals like popularity (Underwood, 2003). The attention that drama brings can increase one's status; drama can also undercut a rival or shore up one's popularity by demonstrating knowledge.

\section{Entertainment}

The appeal of drama is akin to the drama that plays out in female-targeted tabloid magazines or on reality television shows. In teen shows like The Hills or Jersey Shore, a run-of-the-mill interpersonal conflict can become a huge drama for the benefit of the audience. On Jersey Shore, the ongoing breakup of conflicted couple Ron and Sammi is played out over and over again. Part of the appeal of reality television is seeing "real" people interact (Kjus, 2009). In magazines like Us Weekly or OK!, celebrities are slotted into constantly recycled narratives: romances, breakups, marriages, and births. Similarly, on networked publics like Facebook, MySpace and Tumblr, interpersonal drama is performed for an interested audience. Given the many young women like Kim Kardashian and Lauren Conrad who've become famous for harnessing drama, it's no wonder it is so prevalent in non-famous lives. The cultural logics of celebrity place a high value on techniques to gain publicity, visibility, and attention (Sternberg, 1998). It is unsurprising that we see these playing out every day in high school and college life.

danah: What makes you read somebody's conversation on their Wall? Jennifer, 17, Kansas: It's like a magazine kind of, you just read it. It's there... If there's drama, if it'll be interesting.

Some teens see drama as something entertaining that they can safely watch unfold.

Camille, 15, North Carolina: No, yeah, like everybody will use a quote that somebody said, and then they'll be like, that's so stupid or something, who is 
she, and then another person will say it, and then they'll, like, respond to something else, and kind of making fun of them indirectly, fighting.

Alice: So why do you think someone would do that?

Camille: I don't know, it's drama, kind of entertaining.

There's a very human impulse to seek out information about others (Nippert-Eng, 2010), and social media sites provide that in spades. The term "drama" implies a spectacle or performance. Whether comedy or tragedy, drama unfolds to entertain the audience.

Because drama seems inherently interesting, especially at a distance, a lot of teens look for or cause drama when they're bored.

danah: Why do you think people gossip?

Sasha, 16, Michigan: They have no lives. They're bored with their own drama.

danah: So drama is boredom?

Bianca, 16, Michigan: A lot of times, yeah.

danah: Why do you think drama happens? What else?

Bianca: People like, like Sasha said, they're bored or like they're just like not happy, like with their own lives, and they want to make someone else's look like it's not that great or like there's something wrong with them.

Bianca alludes to the idea that girls pick fights with others when they're not happy with their own lives. This shows that attention can be a powerful mechanism for validation and visibility.

\section{The Cultural Work of Drama}

Beyond the practical manifestation of drama, the use of "drama" does significant cultural work for teenagers. It allows teens to blur the boundaries of real conflict and jokes, between hurt and entertainment. This makes it possible for teens to frame their own engagement in social conflict in ways that are distinct from the perpetrator/victim subjectivities of bullying narratives, which are often set and defined by adults. This serves

as an empowerment strategy for teens, who can dismiss a truly hurtful joke by labeling it as "drama." Drama also serves to reinforce the very conventional gendered norms of high school, perpetrating the systemic undervaluing of feminine subjects and re-inscribing heteronormativity. While teens could not explain this cultural work in their own narratives, analyzing their anecdotes and explanations makes it clear that "drama" has a function beyond its status as a popular slang term.

The Social, Psychological, and Cultural Work of Distinguishing Drama from Bullying 
By using the term "drama" rather than gossip, bullying, arguing, or any other similar practice, teens are able to disengage with adult narratives and both create and participate in their own. As mentioned previously, some forms of drama may involve acts that adults identify as bullying, suggesting that drama and bullying are synonymous concepts, but they are not. Instead, by using the language of drama to refer to an array of different practicessome emotionally devastating, others lightweight and fun - teens attempt to protect themselves from the social and psychological harm involved in accounting both for the pain they feel and the pain they cause others.

The rhetoric surrounding bullying suggests that there are "bullies" and there are the "bullied," but dramas that involve relational aggression often lack a clear perpetrator and victim. More importantly, teens gain little by identifying as either. Social stigmas prevent teens from recognizing that they are weak, and few people are willing to admit that they purposefully hurt others. During our fieldwork, the teens who were least likely to admit being bullied were those most likely to lose social status from being labeled as weak: street-smart inner-city youth. Geeky youth, whether Black or White, admitted to it with some prodding.

Drama also implies something not to be taken seriously, to be risen above, while the adult-defined "bullying" connotes childishness or immaturity to teenagers. When we raise the issue of bullying with high school aged teens, they often tell us that bullying is "so middle school" and that teens "grow out of it." In doing so, they position bullying as immature. Thus, to identify with bullying means to position oneself as immature. Yet, as teens recount incidents in the past when they are willing to admit that they were bullied, they talk about gossip and rumors, fights with friends, getting "picked on" and being excluded. These are often the same markers as drama, but teens don't see them this way. They say that bullying has declined as they grow older. When Alice asked Aarti, a 17year-old from North Carolina, what changed, she remarked: "People don't care anymore." In other words, the practices have not changed, but teens' attitudes towards them have.

Even when bullying and drama take similar forms, teens often eschew bullying as a descriptive category for thinking about what they are experiencing.

danah: How big of an issue is bullying at your school?

Chloe, 15, Atlanta: Not big, because we're a Christian school, so our teachers always tell us to be nice to each other and stuff, and no one's ever mean to anyone. Or unless says something to someone on accident.

They're, like, "Oh, I'm so sorry," and you know.

danah: Is there ever issues with rumors spreading?

Chloe: Oh, yeah, all the time.

danah: How does that play out? 
Chloe: Well, someone starts a rumor and then someone else finds out and they're like - and they, everyone just changes the story around. And once it gets around to the person that it's about, they hate this person. It's just... Vicki, 15, Atlanta: Whoever started it.

Chloe: A bunch of gossip, yeah.

Vicki and Chloe continued describing different dramatic incidents involving them and others. They were quick to defend their school from bullying or aggressively "mean" behavior, but freely admitted that it was full of rumors and gossip. Drama is not recognized as relational aggression or bullying by teens, which allows teens to downplay its seriousness.

As we talked with teens, we were privy to a wide array of different examples of drama, but some struck us as serious relational aggression. For example, in North Carolina, we met Morgan, a 16-year-old who was the target of extensive relational aggression by a female classmate, Cathy. Cathy's boyfriend had pursued Morgan and lied to Cathy about it. Jealous and angry, Cathy began tormenting Morgan, blaming her instead of her boyfriend.

I have these kids that I don't really know and they come up to me and they're like "Yeah, I heard about you." And I'm like "I don't even know you. How'd you hear about me?" I told her that I don't want drama and I don't want her to talk about me and I'm not going to talk about her. But she continues to say things about me. I'm trying to leave it alone but it's kind of hard. She'll text one of my friends and say "Morgan's a skank," and I'll be like "What? What'd I do." And then they'll show me the text message and I'll confront her back, and she'll be like "No, I never said that." And then she'll stick stuff on Facebook.

Morgan told us that she was doing nothing to further the drama, but it kept escalating as Cathy sought support. Morgan was so disturbed by the events taking place that she contemplated leaving school. It was clear when Alice interviewed her that this incident was playing a serious psychological toll on Morgan. The ongoing text messages, Facebook updates, and rumors about Morgan would probably be defined by adults as "bullying," but Morgan's use of the term "drama" allowed her to save face by minimizing the conflict's impact, rather than seeing herself as a victim, and framing Cathy as immature and desperate for attention.

Over and over again, teens talked about how bullying was a thing of the past or something that happens to others, while simultaneously recounting stories that struck us as relational aggression or, in serious cases like Morgan's, as bullying. Yet, the consistency 
Paper to be presented at Oxford Internet Institute's "A Decade in Internet Time: Symposium on the

Dynamics of the Internet and Society" on September 22, 2011.

* Draft Version. Feedback Welcome. *

with which teens rejected the frame of bullying made it clear that the stigma associated with such a label felt like an increased burden.

Ashley, a ninth grader, has gotten into trouble at school for bullying others. She is judgmental and evaluates friends, acquaintances and classmates alike with her own moral code. In our interview, she expressed strong disapproval of people trying to get attention, of teens drinking and partying, or of classmates acting "ghetto." Even the examples she uses of a typical interaction on Facebook reveal her judgmental attitude, which she employs to start fights.

Ashley, 14, Tennessee: I think it's kind of annoying when people dye their hair so much. You'll see on Facebook "I just dyed my hair" and you'll see pictures and stuff. Can't you just make it simple, just leave it as it is. Because I know just like I think they kind of do it for attention. I know girls who cut their hair every two weeks or something and they're like, "Look at my new bangs," "Look at this, look at this." And it's kind of like stick with something. Have that be your something.

Ashley uses gossip and relational aggression as tools to enforce her own moral code, but identifies these incidents simply as drama. Her older sister Abigail sees Ashley as a bully, but Ashley rejects this frame. This has caused serious tensions between the two sisters as Abigail tries to intervene with little success. Meanwhile, Ashley continues to engage with others in ways she sees fit, ignoring both her sister and her parents. Instead, Ashley focuses on how she feels: as though she is unfairly treated by others and is justified in her attitude and actions.

"Drama" allows for a kind of blurriness and liminality in teen practice that is not afforded by "bullying" or "gossip." There is also a spectrum of seriousness with regard to drama. Joking, "talking trash," and serious anger can all fall under the rubric of drama. The very fact that drama constitutes a wide variety of different practices - and the blurriness of their meaning - is actually central to what makes "drama" a valuable concept for teens. By lumping all this into the category of "drama," teens can minimize the pain they feel from being left out or made fun of. Furthermore, by intentionally downplaying its significance, teens use "drama" to distance themselves both from the entertaining situations and the events that cause serious emotional pain. The slipperiness of "drama" lets teens frame the social dynamics and emotional impact of conflict as unimportant, letting them save face as an alternative to feeling like a victim —or a bully themselves. 
During fieldwork, we found that both boys and girls invariably defined drama as a "girl thing." Like relational aggression, drama was perpetuated primarily, or entirely, by young women.

danah: So what's the example of drama?

Alicia, 17, North Carolina: Drama? Just it's mostly between girls. Guys' drama is not really. But girls it's like I don't know just if someone did something that a girl— I mean I feel like it's really typical high school drama if a girl is doing something or is like-a girl is talking to a guy that another girl likes or a girl-it's mostly not Facebook related. But the drama comes out on Facebook.

This illustrates another reason that drama is dismissed as unimportant: because it is about traditionally feminine subjects like dating, gossip, and friendships, which tend to be viewed publicly as frivolous or insignificant (Hoffman, 2009). Both boys and girls reinforce these attitudes and norms.

Matthew, 17, North Carolina: And the thing is they'll write about each other. So if there was two people they'll both be going back and forth not talking directly to each other but just kind of shouting out insults to each other in a way. So each person is writing about the other one just throwing out insults like why they're stupid, dumb, ugly or why they never get boys and it's mostly girls who do it too. I mean I'm not for it or anything but that's kind of where it comes from. And the drama is like if they see pictures, or if they see a friend talking to another person maybe they get jealous or something. It's like a lot of jealousy and anger arises out of that which, I think, is super lame.

For Matthew, "they" refers to girls. Girls are the ones who do drama. However, boys are often the cause of drama, following the script of high school popularity which pins a girl's popularity on her relationships and desirability (Brown, 2005). While drama typically takes place between girls, the object of drama is often a boy. Thus, the expression and perpetration of drama crystallizes conventional sex roles that police teen behavior along heteronormative gender lines.

While many boys admitted that they enjoyed watching drama, they felt social pressure not to engage in it.

danah: Does dating create much drama?

Christopher, 15, Iowa: Amongst the girls it does but not the dudes. danah: In what kind of ways does it create drama for the girls?

Christopher: Like, "Oh my gosh, this happened" and like they cry a lot. 
danah: And the dudes are like eh?

Christopher: Yeah, whatever.

Drama is not seen as masculine. Several girls told us that if two boys had an argument, they would either physically fight or forget it within a few days, whereas drama between girls could drag on and on. In practice, there were plenty of situations in which boys could have long-term conflicts with each other; in some inner-city schools, we heard about "beefs" between boys, which could last years and be based on a real or perceived insult.

More commonly, boys engaged in "pranking" and "punking" where they used social media to play jokes on each other. A briefly-abandoned phone could be snatched up and used to post a ridiculous status update. For example, Matthew, who actively dismisses the kinds of dramas that girls engage in, doesn't recognize that the pranks he and his friends play on one another have a similar valence.

Matthew, 16, North Carolina: So my friend took my phone and my phone has Facebook on it. So he goes on there and he makes an incredibly realistic status, like, "Just got suspended for five days because I-" real mature, but he's like, "I have a boner and I was walking on class and I turned to the left and I knocked some kid's book off the table," or something like that, something that was really funny. But now I'd say literally five weeks later, I'm at work with my coworker, who I don't know at all, but she's like, "I saw on your Facebook that you got suspended. Is that true?" I was like, "Oh no! Not true at all."

While Matthew did not frame this incident as drama, "punking" is the masculine version, allowing boys to create liminal spaces between serious aggression and light entertainment. Although this particular incident of being "punked" caused only a small amount of social embarrassment for Matthew, other pranks are more harmful. As with girls' drama, boys' acts of punking and pranking blur the line between what is hurtful and what is simply funny. The difference often boils down to intention: as long as the intention is good, the act is not problematic. But it is often the case that the intention is muddled. Teens try to convey good intentions, even if they're responding out of spite, hurt, or frustration. They also often claim that they are unable to understand the intentions of the opposite sexanother way in which gender differences are inscribed as 'natural'. Boys, for example, avow that girls' "dramas" are a purported mystery to them, while girls imply that boys' interest in "punking" is peculiar.

High school is an environment in which appropriate gender policing is taken very seriously; the casual homophobia among teenage boys is a way to delineate clear markers between acceptable and unacceptable ways of enacting masculinity (Pascoe, 2007). Although we never heard girls demean someone or something as "gay," we heard this 
language repeatedly from boys. Girls and boys have different rules regulating the language which they believe to be appropriate for navigating social conflicts, revealing how gendered norms are reproduced and solidified through the dramas and squabbles.

Drama is a way to encapsulate and define a host of feminine behaviors - including gossiping, romance, and indirect aggression - as something boys do not engage in. Given that gender is a social construct (Kessler \& McKenna, 1978), the hyper-conformist gender environment of high school is brought into being through such types of classification. But despite these seemingly solid boundaries, it is clear that many boys do involve themselves in drama, at least as spectators and sometimes as participants. Labeling drama as "girl stuff" is a way for boys to distance themselves from behavior they see as feminine and simultaneously diminish the concerns of their female classmates as unimportant.

Drama is a deeply gendered process. It is primarily girl's work. It simultaneously perpetuates a value system in which traditionally feminine, interpersonal subjects are seen as trivial and unimportant, and frames information as valuable social capital. It re-inscribes a heteronormative high school existence where girls compete for male attention, while boys stand one step removed. And it replicates celebrity narratives marketed to young women where minor and mundane interpersonal conflict is exaggerated for effect.

\section{$\underline{\text { Conclusion }}$}

Stan, 18, Iowa: You'd actually be surprised how little things change. I'm guessing a lot of the drama is still the same, it's just the format is a little different. It's just changing the font and changing the background color really.

While teen conflict will never go away, networked publics have changed how it operates. "Drama" is a very messy process, full of contradictions and blurred boundaries. But it opens up spaces for teens. As a concept, drama lets teens conceptualize and understand how their social dynamics have changed with the emergence of social media. Technology allows teens to carve out agented identities for themselves even when embroiled in social conflict. And it lets them save face when confronted with adult-defined dynamics, which their peers see as childish and irrelevant.

In this paper, we have attempted to map out some of the core elements of drama and understand the function that it serves in teenage lives. Understanding how "drama" operates is necessary to recognize teens' own defenses against the realities of aggression, gossip, and bullying in networked publics. Most teens do not recognize themselves in the "bullying" rhetoric used by parents, teen advocates, and mental health professionals. Even the pop cultural depictions in television shows like Glee feel irrelevant to many teens. They do not want to see themselves as victims or as aggressors, but as mature individuals navigating their world competently. Even teens who are clearly instigators of drama brush 
Paper to be presented at Oxford Internet Institute's "A Decade in Internet Time: Symposium on the Dynamics of the Internet and Society" on September 22, 2011.

* Draft Version. Feedback Welcome.*

off its significance, enjoying the attention, emulating the excitement of celebrity culture, and unquestioningly reproducing the gender norms around them. These dynamics are different from those described in bullying narratives. We hope that future research will address these distinctions in order to fully understand the realities of teenage interaction in the networked age.

\section{$\underline{\text { References }}$}

boyd, danah. (2008). Taken out of context: American teen sociality in networked publics. University of California, Berkeley. Retrieved from http://papers.ssrn.com/sol3/papers.cfm?abstract_id=1344756

boyd, danah, \& Marwick, A. (2011). Social Privacy in Networked Publics: Teens' Attitudes, Practices, and Strategies. Presented at the Privacy Law Scholars Conference, Berkeley, CA.

Brown, L. M. (2005). Girlfighting: Betrayal and Rejection Among Girls. NYU Press.

Fine, G. A. (1986). The social organization of adolescent gossip: The rhetoric of moral evaluation. In J. Cook-Gumperz, W. A. Corsaro, \& J. Streeck (Eds.), Children 's worlds and children's language (pp. 405-423). New York: Mouton de Gruyter.

Fine, G. A. (1997). Gossip. In T. A. Green (Ed.), Folklore: an encyclopedia of beliefs, customs, tales, music, and art (pp. 422-423). Santa Barbara, CA: ABC-CLIO.

Goffman, E. (1959). The presentation of self in everyday life. New York: Doubleday.

Goffman, E. (1967). "On Face-Work: An Analysis of Ritual Elements in Social Interactions." In Interaction Ritual: Essays on Face-to-Face Behavior. New York: Pantheon Books, pp. 5-45.

Hoffman, A. (2009, August). Oversharing: A critical discourse analysis (Master of Library and Information Science Thesis). University of Wisconsin-Milwaukee, Milwaukee, WI.

Jack, D. C. (1999). Behind the mask: destruction and creativity in women's aggression. Cambridge, MA: Harvard University Press.

Kessler, S. J., \& McKenna, W. (1978). Gender: An ethnomethodological approach. University of Chicago Press.

Kjus, Y. (2009). Idolizing and monetizing the public: The production of celebrities and fans, representatives and citizens in reality TV. International Journal of 
Paper to be presented at Oxford Internet Institute's "A Decade in Internet Time: Symposium on the

Dynamics of the Internet and Society" on September 22, 2011.

* Draft Version. Feedback Welcome. *

Communication, 3, 277-300.Marwick, A. (2011). The Public Domain: Social Surveillance in Everyday Life. Presented at Social Surveillance in Every Day Life, Toronto.

Milner, M., Jr. (2004). Freaks, Geeks, and Cool Kids: American Teenagers, Schools, and the Culture of Consumption. New York: Routledge.

Ness, C. (2010). Why Girls Fight: Female Youth Violence in the Inner City. New York: NYU Press.

Nippert-Eng, C. E. (2010). Islands of privacy. Chicago: University of Chicago Press.

Olweus, D. (2011). What is Bullying? Definition, statistics \& Information on Bullying. Olweus Bullying Prevention Program. Retrieved September 7, 2011, from http://www.olweus.org/public/bullying.page

Pascoe, C. J. (2007). Dude, You're a Fag: Masculinity and Sexuality in High School (1st ed.). Berkeley, CA: University of California Press.

Remillard, A. M., \& Lamb, S. (2005). Adolescent Girls' Coping With Relational Aggression. Sex Roles, 53(3-4), 221-229. doi:10.1007/s11199-005-5680-8

Simmons, R. (2003). Odd girl out: the hidden culture of aggression in girls. Houghton Mifflin Harcourt.

Sternberg, E. (1998). Phantasmagoric labor: The new economics of self-presentation. Futures, 30(1), 3-21.Underwood, M. K. (2003). Social aggression among girls. New York: Guilford Press.

Urban Dictionary. (2005). Urban Dictionary: drama. Urban Dictionary. Retrieved September 10, 2011, from http://www.urbandictionary.com/define.php?term=drama

Veinot, T. C., Campbell, T. R., Kruger, D., Grodzinski, A., \& Franzen, S. (2011). Drama and danger: The opportunities and challenges of promoting youth sexual health through online social networks. Improving Health: Informatics and IT changing the world. Presented at the AMIA 2011 Annual Symposium, Washington, DC.

Wiseman, R. (2003). Queen Bees \& Wannabes. New York: Crown Publishing. 